\title{
Access to School Counseling and the Connection to Postsecondary STEM Outcomes
}

\section{Dana L. Brookover}

Access to school counseling services leads to access to college-readiness counseling initiatives, including science, technology, engineering, and mathematics (STEM) education-focused counseling for students. School counselor caseload and percentage of time spent on college-readiness counseling were analyzed in relation to longitudinal STEM postsecondary outcomes of students in a nationally representative sample. Access to school counselors who spend $21 \%$ or more of their time on college-readiness counseling predicted persistence and attainment of a STEM postsecondary degree. The current results offer implications for school counselors, counselor educators, and future researchers, including the need for STEM self-efficacy interventions, unbiased curriculum, and professional development on STEM counseling for school counselors; and the call for a more nuanced understanding of this topic.

Keywords: STEM, school counseling, college-readiness counseling, longitudinal, self-efficacy

College and career readiness are key outcome targets of school systems across the United States (Malin et al., 2017; U.S. Department of Education, 2010). Science, technology, engineering, and mathematics (STEM) initiatives are also a national priority (The White House, Office of Science and Technology Policy, National Science and Technology Council, 2018). School counselors play an integral role in their students' college readiness through providing college-readiness counseling (Gilfillan, 2017). This includes the important role school counselors perform in educating students on the possibilities in STEM at the college level (Cabell et al., 2021; Schmidt et al., 2012).

\section{STEM Education}

STEM education has been described by Tsupros and colleagues (2009) as an interdisciplinary approach to learning science, technology, engineering, and mathematics that includes understanding and knowledge of science and math concepts, computers, and problem-solving skills. There have been longstanding calls for a more STEM-literate workforce, a more diverse STEM workforce, and more individuals interested in working in the STEM fields in general (Mohr-Schroeder et al., 2015).

STEM education attainment and persistence is an emerging topic in the career development and counseling profession, but there are differing opinions on what constitutes the "STEM crisis" (Xue \& Larson, 2015). Some researchers have indicated that the demand for STEM workers in the United States will not be met because of a lack of qualified and interested individuals to step into these positions. Another viewpoint emphasizes that research has indicated there are both shortages and surpluses of STEM workers, depending on the particular job market segment (Xue \& Larson, 2015). Still, the data is clear that there is a "STEM crisis" in terms of inequities in who is matriculating into and persisting in STEM majors (National Science Foundation [NSF], 2021).

Despite the great growth in traditionally underrepresented students persisting in STEM majors in college (NSF, 2021) and the potential for career development initiatives to increase retention in STEM for minority groups (Belser et al., 2018), there are still disparities in STEM college major attainment and

Dana L. Brookover, PhD, NCC, is a licensed school counselor and an assistant professor at the University of Scranton. Correspondence may be addressed to Dana L. Brookover, McGurrin Hall Room 435, McGurrin Hall, The University of Scranton, Scranton, PA 18510, brookoverdl@gmail.com. 
persistence by gender, race and ethnicity, socioeconomic status (SES), and first-generation college student (FGCS) status (Chen, 2013). This is an equity issue, as the choice to enroll in a STEM postsecondary program may also lead to higher pay and the potential for positive job marketability given the projected growth in available positions (Cataldi et al., 2014; Vilorio, 2014). Hence, school counselors are called upon to address STEM education disparities in their work, as the American School Counselor Association (ASCA; 2019) emphasizes the role of the school counselor in working to ensure equitable postsecondary opportunities and outcomes for all students.

\section{College-Readiness Counseling and STEM Education}

High school counselors are in a unique position to provide career-readiness counseling, including college-readiness counseling for those students who aim to attend college after high school. Collegereadiness counseling involves developmentally appropriate counseling that engages students in (a) creating postsecondary goals and expectations, (b) building an awareness of interests and abilities, and (c) receiving information and support for their college access and success (Savitz-Romer, 2012). School counselors can focus on STEM education with students in each of these tasks.

Research has shown that students' intent to pursue a STEM career already varies by populations as early as the ninth grade. Girls and students in minority racial groups, in a nationally representative sample, were less likely to expect to work in a STEM discipline at the age of 30 as compared to boys and White students (Mau \& Li, 2018). Students' SES also predicted STEM career aspirations, in that a student with higher SES was more likely to aspire to a STEM career (Mau \& Li, 2018). There are multiple potential reasons for the opportunity gaps in STEM higher education, including lack of engagement in higher-level STEM coursework in high school, the time it takes to complete STEM programs, and a student's lack of financial ability to do so, as well as attitudinal factors, such as motivation and confidence. These factors can lead to less matriculation into a STEM major and more attrition (Chen, 2013). There may also be a lack of support and encouragement and even direct discouragement from educators for underrepresented minorities and women to engage in STEM coursework, starting in adolescence (Grossman \& Porche, 2014). This was echoed in a qualitative study in which high school counselors said that a barrier in their work supporting underrepresented students in STEM was a lack of anti-racist curricula in STEM classes and inconsistencies in anti-racist practice by teachers (Cabell et al., 2021). The importance of collegereadiness counseling focused on STEM education is known.

\section{Existing STEM Education-Focused College-Readiness Counseling Research}

Emerging research is developing on the school counselor's role on students' STEM self-efficacy and students' pursuit of postsecondary STEM education (Cabell et al., 2021; Falco, 2017; Falco \& Summers, 2019; Schmidt et al., 2012). Falco (2017) provided a conceptual framework with the goal of helping school counselors better support STEM career development for all students and especially those from underrepresented groups. Falco suggested school counselors can encourage students to take advanced-level math and science courses, provide classroom instruction on the benefits of engaging in STEM, ensure balanced gender and racial/ethnic ratios in STEM classes, and organize a peer mentoring program or conduct small group counseling on relevant skills.

Cabell and colleagues (2021) interviewed high school counselors about their work with underrepresented students and STEM education. The participants were actively engaging in collegereadiness counseling focused on STEM education with students, but there were barriers to their ability to support underrepresented students' STEM interests, including lack of time, in part from administrative tasks, and large caseloads (Cabell et al., 2021). This is related to previous research suggesting that the percentage of time spent on college-readiness counseling differs by school characteristics. For example, 
private school counselors typically spend more time on it than public school counselors, and school counselors with more students on free-and-reduced lunch tend to spend less time (Clinedinst \& Koranteng, 2017). Smaller caseloads have also been associated with school counselors spending more than half their time on college-readiness counseling (Engberg \& Gilbert, 2014). Further, smaller caseloads show improved college outcomes, including higher rates of 4-year college enrollment (Engberg \& Gilbert, 2014; Hurwitz \& Howell, 2014).

Schmidt and colleagues (2012) also provided suggestions for school counselors to "expand their repertoire" through STEM-focused career development. Key impact areas include academic and career counseling, and leadership and advocacy. The researchers acknowledged how school climate and the large administrative demands (i.e., duties inappropriate for counselors) placed on school counselors may restrict their ability to engage in career-related and STEM course discussions with students. However, there is no data to shed light on the long-term impacts of this barrier and how their suggested key impact areas influence student outcomes.

Research has found that self-efficacy is an important pathway to students' STEM major persistence (Lent et al., 2016; Rittmayer \& Beier, 2009). Self-efficacy is an individual's belief in their ability to influence and control the events of their life to obtain desired performances (Bandura, 1994). As an example, when students believe they can achieve desired results in science through their abilities and actions, this is considered high science self-efficacy. Researchers have detailed the results of a career group intervention that incorporated the sources of self-efficacy and addressed perceived career barriers with the goals of improving the career decision self-efficacy and STEM self-efficacy for adolescent girls (Falco \& Summers, 2019). Components of the intervention included a group counseling structure, career psychoeducation, journaling, constructing a timeline of successful previous performances, progressive muscle relaxation, vicarious learning, and verbal persuasion by the leader. Results showed significantly different improvements in career decision self-efficacy and STEM self-efficacy. The results of this intervention are promising, especially as it is one of the few empirical studies on self-efficacy counseling interventions and STEM career outcomes with adolescents. The sample was all female with half of the sample identifying as Latina (Falco \& Summers, 2019).

It follows that there needs to be access to school counseling services for engagement in college counseling that can effectively bolster students' STEM aspirations. Given the potential for high school STEM interventions to make a great impact in student's STEM self-efficacy and education outcomes, the inability of school counselors to provide college counseling, and specifically STEM-focused college counseling, is troubling (Falco \& Summers, 2019). To move forward in advocating for school counseling access to promote student outcomes in the STEM pipeline, a theory-driven, longitudinal approach to investigating the impact of school counseling access on this outcome was initiated in the current study. Given the importance of considering student characteristics, environmental inputs, and self-efficacy in STEM matriculation, attainment, and persistence, social cognitive career theory (Lent et al., 1994) served as a logical base for the theoretical framework for this investigation.

\section{Social Cognitive Career Theory}

Social cognitive career theory (SCCT) was developed from Albert Bandura's (1986) social cognitive theory to create a unifying theory of career and academic interest, choice, and performance (Lent et al., 1994). SCCT accounts for the cyclical nature of making a career choice through accounting for people receiving information from contextual influences that fuel feedback loops (Lent, 2004). These external influences can be contextual supports or barriers (Lent et al., 2000). It is also important to note that one's perception of barriers moderates the relationship between interests and career choices (Brown \& 
Lent, 1996). Hence, underrepresented and underserved students' perceptions of barriers in obtaining a STEM degree can impact career choice and development. Moreover, other background environmental influences, person inputs, and behaviors interact in this feedback loop as well. One influence of utmost importance in the theory is self-efficacy. Thus, SCCT can account for external factors, otherwise known as proximal environmental influences (e.g., school counseling access), and individual characteristics (e.g., demographics and self-efficacy) within long-term career development formation.

\section{Purpose of the Study}

The current study was built upon previous SCCT school counseling and STEM attainment and persistence studies. The goal was to investigate the long-term impacts of school counseling access, in relation to student characteristics, on STEM outcomes. The research question guiding the study was: Do school counselor caseload and percentage of time spent on college-readiness counseling predict STEM major attainment and persistence?

\section{Method}

Using a multivariate, quantitative, longitudinal research design to answer the research question was well-suited to the purpose of the study. Longitudinal research designs allow for gathering and analyzing data on development over time (Lavrakas, 2008). As the research question was focused on prediction in a sample of students and the outcome was measured quantitatively, this research design was employed. I followed the process of secondary analysis of existing data (Cheng \& Phillips, 2014), utilizing the High School Longitudinal Study of 2009 (HSLS:09), developed by the National Center for Education Statistics (NCES; 2020a). The HSLS:09 dataset followed a sample of high school students throughout their secondary education career into postsecondary years (NCES, 2020b).

\section{Participants and Sampling}

The HSLS:09 is a longitudinal study of over 23,000 ninth graders from 944 schools (Ingels \& Dalton, 2013; NCES, 2020b). Stratified random sampling ensured a nationally representative sample. Approximately 900 high school counselors were surveyed for the study to provide information on their school counseling departments, including school counselor caseload and percentage of time spent on college-readiness counseling. School counselors in the study were not randomly selected; rather, they were either the lead counselor or the counselor deemed most knowledgeable about the ninth graders at the time of the baseline data collection (Ingels \& Dalton, 2013). The baseline data was collected in 2009, then the study had a first follow-up survey with student participants in 2012; there was a brief 2013 update survey and a second follow-up in 2016 (Duprey et al., 2018).

\section{Data Selection}

Cheng and Phillips's (2014) steps for secondary analysis of existing data under the research question-driven approach guided the data collection procedures for the current study. Thus, I determined which variables in the existing dataset to use to answer the research question. This was done through using SCCT to guide the model creation. Then, I became acquainted with the coding patterns of variables. This led to the transformation of distributions of select variables to meet assumptions of the model to be used in analysis when necessary, as detailed below.

\section{Constructs and Variables}

The HSLS:09 variables (NCES, 2020a) included in the current study both cover the research question and fit within the theoretical framework (i.e., SCCT; Lent et al., 1994). First, there are demographic variables, also known as person inputs and background environmental influences, within 
SCCT. Data on variables to represent self-efficacy constructs were also selected. Two variables measured school counselor caseload and school counselor percentage of time spent on collegereadiness counseling. Finally, the outcome variable was STEM major attainment and persistence.

\section{First-Generation College Student Status}

The FGCS status variable was constructed as a variable detailing the highest level of education achieved by either parent/guardian in the sample member's home in the HSLS:09 dataset. This was created from two composite variables within the dataset: highest education level of Parent 1 and highest education level of Parent 2. In its original categorical form, there are seven categories for parent highest level of education, but for the current study, it was recoded into a dichotomous/dummy variable; either the student had a parent in the home who has a bachelor's degree or a more advanced degree, or the student did not have a parent in the home who has a bachelor's or a more advanced degree.

\section{Race/Ethnicity}

Race/ethnicity information was provided through dichotomous race/ethnicity composites based on data from the student questionnaire, if available. If not available from the student questionnaire, they were based on, in order of preference: data from the school-provided sampling roster or data from the parent questionnaire. The designations included in the HSLS:09 and the current study are: (a) American Indian or Alaskan Native; (b) Asian; (c) Black (African American); (d) Hispanic, no race specified; (e) Hispanic, race specified; (f) more than one race; (g) Native Hawaiian/Pacific Islander; and (h) White. For the current study, the two Hispanic categories were combined.

\section{Sex}

This variable was categorical and referred to the sex of the sample member (male or female) and was provided by the student if possible, and if not, the parent or school roster. The labels male and female have held and continue to hold "powerful associations" (Lips, 2020, p. 3), and not all people identify into a gender binary of female and male (Lips, 2020). There is a gender variable assessed in the HSLS:09 study; however, it is only available in the restricted use dataset, so the sex variable was utilized in the current study.

\section{Socioeconomic Status}

SES was a composite variable consisting of five components obtained from the parent/guardian questionnaire and aligned with previous NCES longitudinal study methods for calculating SES: (a) the highest education among parents/guardians in the two-parent family of a responding student, or the education of the sole parent/guardian; (b) the education level of the other parent/guardian in the twoparent family; (c) the highest occupational prestige score among parents/guardians in the two-parent family of a responding student, or the prestige score of the sole parent/guardian; (d) the occupation prestige score of the other parent/guardian in the two-parent family; and (e) family income. This was a standardized value set to 0 ; hence, values ranged from -1.82 to 2.57 .

\section{Self-Efficacy Variables}

This data was collected at the baseline. SCCT asserts that learning experiences and prior accomplishments are an integral part of forming self-efficacy; hence STEM grade point average (GPA) was included under self-efficacy (Lent et al., 1994). GPA information was collected at the 2013 update.

Math Self-Efficacy. Math self-efficacy is a continuous variable, with higher values representing higher math self-efficacy. The information was assessed through a scale consisting of four items (e.g., "can do excellent job on math tests"). The variable was created through principal components 
factor analysis and was standardized to a mean of 0 and standard deviation of 1 . Only respondents who provided a full set of responses were assigned a scale value. The coefficient of reliability (demonstrated by alpha) for the scale is .65 (NCES, 2020c).

Science Self-Efficacy. Science self-efficacy is also a continuous variable, with higher values representing higher science self-efficacy, and was also created through principal components factor analysis and standardized to a mean of 0 and standard deviation of 1 . There were four items on the scale (e.g., "can master skills in science course"). Only respondents who provided a full set of responses were assigned a scale value. The coefficient of reliability (indicated by alpha) for the scale is .65 (NCES, 2020c).

\section{STEM GPA}

STEM GPA, an interval variable, was computed during the 2013 update through high school transcript composites. STEM GPA values range from 0.25 to 4 , in increments of 0.25 .

\section{School Counselor Caseload}

Information for this continuous variable was assessed through one item on the school counselor questionnaire: "On average, what is the caseload for a counselor in this school? Students per counselor." Students per counselor ranged from 2 to 999 (NCES, 2020c). The variable was recoded into a dichotomous variable, with 0 indicating a school counselor caseload of 250 or less, and 1 indicating a school counselor caseload of 251 or more. The ASCA-recommended caseload number for school counselors is 250:1.

\section{School Counselor Percentage of Time Spent on College-Readiness Counseling}

This was assessed through one item on the school counselor questionnaire that read, "Last school year (2008-2009), what percentage of work hours did your school's counseling staff spend assisting students with college readiness, selection, and applications?" Responses were reported according to the following categories: $5 \%$ or less, $6 \%-10 \%, 11 \%-20 \%, 21 \%-50 \%$, and more than $50 \%$. This was recoded to a dichotomous variable $-20 \%$ or less time spent on college-readiness counseling or $21 \%$ or more time spent on college-readiness counseling - reflecting a cut-off of the national average of time spent on college-readiness counseling by school counselors at 21\% (Clinedinst \& Koranteng, 2017).

\section{Outcome Variable: STEM Major Attainment and Persistence}

This was a dichotomous variable (either Not STEM or STEM) and was collected in the second follow-up study in 2016 (i.e., approximately 3 years post-high school graduation). It referred to how the respondent declared or decided upon their degree and whether that undergraduate degree or certificate is in a STEM field of study.

\section{Data Analysis}

Continuing to follow Cheng and Phillips's (2014) steps for secondary analysis of existing data, the first step in data analysis was to run preliminary analyses of descriptive statistics and bivariate correlations. Then, I assessed missing data patterns. When deemed necessary, the HSLS:09 developers did utilize imputation of values (Ingels \& Dalton, 2013). Imputation allows the use of all study respondent records in an analysis, affording more power for statistical tests. Additionally, if the imputation procedure is effective, then the analysis results can be less biased than if there were missing data unaccounted for (Ingels \& Dalton, 2013). Value imputation occurred in place of missing responses for select variables identified from the student and parent questionnaires through single-value 
imputation (Duprey et al., 2018; Ingels \& Dalton, 2013). Further, the NCES provides analytic weighted variables and replication weights associated with those main sampling weights. The analytic weights make estimates from the sample data representative of the target population (i.e., ninth grade students in 2009-2010). These analytic weights account not only for differential selection probabilities, but also for differential patterns of response and nonresponse-in other words, nonresponse bias (Duprey et al., 2018). In addition to the analytic weight variables accounting for stratified sampling and nonresponse bias, replication weight variables address standard error concerns. Standard error calculation ensures appropriate standard errors based on the differences between the estimates of the full sample and a series of replicates (Duprey et al., 2018). These replication weights are done with the balanced repeated replication method and help account for the possibility of artificially low standard errors due to clustering in sampling (Duprey et al., 2018).

Prior to running the sequential logistic regression, assumptions testing was completed. Logistic regression analyses allow the use of criterion measures on a binary outcome (Meyers et al., 2017). The result of a logistic regression is the impact of each variable on the probability of the observed event of interest (Sperandei, 2014). Sequential logistic regression allows the researcher to specify the entry order of predictor variables into the model (Tabachnick \& Fidell, 2013).

Model 1, the baseline model, represented person inputs and background environmental influences in SCCT. It included the following variables: FGCS status, race/ethnicity, sex, and SES. Model 2 represented self-efficacy, after controlling for person inputs and background environmental influences. Self-efficacy variables included math self-efficacy, science self-efficacy, and STEM GPA. Model 3 examined school counseling access, after controlling for the variables in the previous two models. School counseling access variables were school counselor caseload and school counselor percentage of time spent on collegereadiness counseling. Table 1 displays the model steps and variables.

\section{Table 1}

Logistic Regression Model Steps

\begin{tabular}{lll}
\hline Step & Variables & SCCT Tenets \\
\hline 1 & First-generation student status & \\
& Race/ethnicity & $\begin{array}{l}\text { Person inputs and background } \\
\text { environmental influences }\end{array}$ \\
& Sex & \\
\hline 2 & Socioeconomic status & \\
& Math Self-Efficacy & Self-efficacy \\
& Science Self-Efficacy & \\
\hline 3 & STEM GPA & Proximal environmental influences \\
\hline
\end{tabular}

Note. SCCT $=$ Social Cognitive Career Theory. 


\section{Results}

The aim of the current study was to examine the predictors of STEM major attainment and persistence, including school counselor caseload ratio and percentage of time spent on college-readiness counseling. First, preliminary analysis included running descriptive statistics and a correlation matrix.

\section{Preliminary Analysis}

Frequencies and percentages on the variables' unweighted, valid data (i.e., data before weights were applied and not including missing data) are reported in this section. First, descriptive statistics on person inputs and background environmental influences (i.e., student demographics) were collected. A total of $56.4 \%(n=9,468)$ of the valid sample were FGCS, and $43.6 \%(n=7,314)$ were non-FGCS. A total of $50.9 \%(n=11,973)$ of the sample were identified as female, and the remaining $49 \%(n=11,524)$ as male. The continuous SES variable ranged from -1.93 to 2.88 , with a mean score of $0.05(S D=0.78)$. For information on participants' race/ethnicity, see Table 2.

\section{Table 2}

Participant Race and Ethnicity Variable Percentages and Frequencies

\begin{tabular}{lcc}
\hline Race / Ethnicity & Valid Percentage (\%) & Valid $n$ \\
\hline American Indian or Alaskan Native & $0.7 \%$ & 165 \\
Asian & $8.7 \%$ & 1,952 \\
Black (African American) & $10.9 \%$ & 2,450 \\
Hispanic & $16.9 \%$ & 3,797 \\
More than one race & $8.6 \%$ & 1,941 \\
Native Hawaiian / Pacific Islander & $0.5 \%$ & 110 \\
White & $53.7 \%$ & 12,082 \\
\hline Total & $100 \%$ & 22,497 \\
\hline
\end{tabular}

Math self-efficacy scores ranged from -2.92 to $1.62(M=0.0421, S D=0.96)$. Science self-efficacy scores ranged from -2.91 to $1.83(M=.0372, S D=0.99)$. In terms of STEM GPA, the range was 0.25 through 4.00, reported in intervals of $0.25(M=2.43, S D=0.93)$.

The school counselor caseload in the current study had a mean score of 347.65 students $(S D=130)$, ranging from 2-999. The median was 350. The school counselor percentage of time spent on collegereadiness counseling scores ranged from $1-5(M=3.37, S D=0.95)$. A total of $2.3 \%(n=484)$ chose $5 \%$ or less, and $16.2 \%(n=3,389)$ of the sample chose $6 \%-10 \%$. A total of $33.8 \%(n=7,094)$ indicated $11 \%-20 \%$, followed by $37.5 \%(n=7,867)$ choosing $21 \%-50 \%$. Finally, $10.2 \%(n=2,132)$ of the sample chose the more than $50 \%$ option.

For the STEM major persistence and attainment variable, $23 \%(n=2,658)$ of the valid sample were enrolled as a STEM major or had attained a STEM degree as of February 2016, and 77\% $(n=8,902)$ were neither enrolled as a STEM major nor had attained a STEM degree as of February 2016. 


\section{Bivariate Correlations}

A bivariate correlational analysis of interval and ratio variables in the study allowed for preliminary examination of collinearity and provided information on relationships between the variables of interest. The bivariate correlation matrix indicated no concerns regarding multicollinearity. The correlations contain indications of relationships to school counseling access. For example, school counseling caseload and percentage of time spent on college-readiness counseling were inversely related $(r=-.181, p<.01)$. School counselor caseload was negatively significantly correlated to SES, STEM GPA, and math selfefficacy. School counselor percentage of time spent on college-readiness counseling was positively significantly correlated with SES, STEM GPA, math self-efficacy, and science self-efficacy. See Table 3 for the full results of the bivariate correlations.

\section{Table 3}

\section{Bivariate Correlations}

\begin{tabular}{|c|c|c|c|c|c|c|}
\hline Variables & 1 & 2 & 3 & 4 & 5 & 6 \\
\hline 1. SES & - & & & & & \\
\hline 2. STEM GPA & $.398^{* *}$ & - & & & & \\
\hline 3. Math self-efficacy & $.152^{* *}$ & $.302^{* *}$ & - & & & \\
\hline 4. Science self-efficacy & $.15^{* *}$ & $.223^{* *}$ & $.395^{* *}$ & - & & \\
\hline 5. School counseling caseload & $-.152^{* *}$ & $-.105^{* *}$ & $-.045^{* *}$ & -.015 & - & \\
\hline $\begin{array}{l}\text { 6. Percentage of time spent on } \\
\text { college-readiness counseling }\end{array}$ & $.150^{* *}$ & $.104^{* *}$ & $.042^{* *}$ & $.027^{* *}$ & $-.181^{* *}$ & - \\
\hline
\end{tabular}

Note. SES = socioeconomic status; STEM = science, technology, engineering, mathematics; GPA = grade point average. ${ }^{* *} p<.01$.

\section{Primary Analysis}

Next, the results of the sequential logistic regression are presented (see Table 4). The outcome variable is a dichotomous variable of STEM major persistence and attainment and indicated if a student either is or is not enrolled as a declared STEM major in a postsecondary institution or has or has not attained a degree in a STEM field from a postsecondary institution.

Statistical assumptions of the model were assessed. Tolerance (0.26) and VIF values (mean $\mathrm{VIF}=1.34$ ) indicated no concerns regarding multicollinearity. The Box-Tidwell test indicated the assumption of a linear relationship between continuous predictors and the logit transform of the outcome variable was met, with nonsignificant $p$ values. Utilizing the balanced repeated replication variance estimation method, 16,007 observations were included in the regression model, with a population size of 1,540,118 and 192 replications. 
Table 4

Logistic Regression Model Predicting STEM Major Attainment and Persistence

\begin{tabular}{|c|c|c|c|c|c|c|c|c|c|}
\hline \multirow[b]{2}{*}{ Predictor } & \multicolumn{3}{|c|}{ Model 1} & \multicolumn{3}{|c|}{ Model 2} & \multicolumn{3}{|c|}{ Model 3} \\
\hline & $\beta$ & $S E$ & OR (CI) & $\beta$ & $S E$ & OR (CI) & $\beta$ & $S E$ & OR (CI) \\
\hline FGCS & -0.15 & 0.12 & $\begin{array}{c}0.86 \\
(0.68-1.10)\end{array}$ & -0.16 & 0.15 & $\begin{array}{c}0.86 \\
(0.64-1.14)\end{array}$ & -0.26 & 0.14 & $\begin{array}{c}0.77 \\
(0.59-1.02)\end{array}$ \\
\hline \multicolumn{10}{|l|}{ Race / Ethnicity } \\
\hline $\begin{array}{l}\text { American Indian or } \\
\text { Alaskan Native }\end{array}$ & -0.45 & 0.85 & $\begin{array}{c}0.64 \\
(0.12-3.44)\end{array}$ & -0.13 & 1.01 & $\begin{array}{c}0.88 \\
(0.12-6.34)\end{array}$ & -0.13 & 1.15 & $\begin{array}{c}0.87 \\
(0.09-8.48)\end{array}$ \\
\hline Asian & $0.91^{* * *}$ & 0.21 & $\begin{array}{c}2.48 \\
(1.65-3.73)\end{array}$ & $0.89^{* * *}$ & 0.24 & $\begin{array}{c}2.45 \\
(1.52-3.94)\end{array}$ & $0.92^{* *}$ & 0.27 & $\begin{array}{c}2.50 \\
(1.48-4.23)\end{array}$ \\
\hline $\begin{array}{l}\text { Black (African } \\
\text { American) }\end{array}$ & -0.09 & 0.17 & $\begin{array}{c}0.92 \\
(0.65-1.29) \\
\end{array}$ & 0.22 & 0.22 & $\begin{array}{c}1.24 \\
(0.81-1.91) \\
\end{array}$ & 0.23 & 0.24 & $\begin{array}{c}1.26 \\
(0.78-2.04)\end{array}$ \\
\hline Hispanic & 0.11 & 0.15 & $\begin{array}{c}1.12 \\
(0.83-1.51)\end{array}$ & $0.38^{*}$ & 0.18 & $\begin{array}{c}1.46 \\
(1.02-2.08) \\
\end{array}$ & $0.44^{*}$ & 0.19 & $\begin{array}{c}1.56 \\
(1.07-2.28)\end{array}$ \\
\hline More than one race & -0.05 & 0.15 & $\begin{array}{c}0.95 \\
(0.71-1.28)\end{array}$ & 0.09 & 0.17 & $\begin{array}{c}1.10 \\
(0.78-1.55)\end{array}$ & 0.13 & 0.19 & $\begin{array}{c}1.14 \\
(0.78-1.65)\end{array}$ \\
\hline $\begin{array}{l}\text { Native Hawaiian / } \\
\text { Pacific Islander }\end{array}$ & 0.67 & 0.81 & $\begin{array}{c}1.97 \\
(0.40-9.65) \\
\end{array}$ & 0.58 & 0.82 & $\begin{array}{c}1.78 \\
(0.35-9.03) \\
\end{array}$ & 0.51 & 1.00 & $\begin{array}{c}1.67 \\
(0.23-12.05) \\
\end{array}$ \\
\hline Sex & $-0.94^{* * *}$ & 0.10 & $\begin{array}{c}0.39 \\
(0.32-0.48) \\
\end{array}$ & $-0.93^{* * *}$ & 0.11 & $\begin{array}{c}0.39 \\
(0.32-0.49) \\
\end{array}$ & $-0.94^{* * *}$ & 0.12 & $\begin{array}{c}0.39 \\
(0.31-0.50)\end{array}$ \\
\hline SES & $0.22^{* *}$ & 0.08 & $\begin{array}{c}1.25 \\
(1.06-1.46) \\
\end{array}$ & 0.07 & 0.10 & $\begin{array}{c}1.07 \\
(0.89-1.30) \\
\end{array}$ & 0.01 & 0.09 & $\begin{array}{c}1.01 \\
(0.85-1.21) \\
\end{array}$ \\
\hline Math self-efficacy & & & & $0.27^{* * *}$ & 0.06 & $\begin{array}{c}1.31 \\
(1.17-1.47) \\
\end{array}$ & $0.27^{* * *}$ & 0.07 & $\begin{array}{c}1.31 \\
(1.16-1.49) \\
\end{array}$ \\
\hline Science self-efficacy & & & & $0.26^{* * *}$ & 0.07 & $\begin{array}{c}1.30 \\
(1.14-1.47) \\
\end{array}$ & $0.26^{* * *}$ & 0.07 & $\begin{array}{c}1.30 \\
(1.13-1.50) \\
\end{array}$ \\
\hline STEM GPA & & & & $-0.64^{* * *}$ & 0.13 & $\begin{array}{c}0.86 \\
(0.64-1.14) \\
\end{array}$ & $-0.65^{* * *}$ & 0.14 & $\begin{array}{c}0.52 \\
(0.40-0.68)\end{array}$ \\
\hline $\begin{array}{l}\text { School counselor } \\
\text { caseload }\end{array}$ & & & & & & & 0.00 & 0.00 & $\begin{array}{c}1.00 \\
(1.01-1.65) \\
\end{array}$ \\
\hline $\begin{array}{l}\text { Percentage of time spent } \\
\text { on college-readiness } \\
\text { counseling }\end{array}$ & & & & & & & $0.26^{*}$ & 0.12 & $\begin{array}{c}1.29 \\
(1.01-1.65)\end{array}$ \\
\hline
\end{tabular}

Note. Model 1 = person inputs and background environmental influences (first-generation college student [FGCS], race/ ethnicity, sex, socioeconomic status [SES]), without any controls; Model 2 = person inputs and background environmental influences, and self-efficacy variables (math self-efficacy, science self-efficacy, and STEM grade point average [GPA]); Model 3 = person inputs and background environmental influences, self-efficacy variables, and proximal environmental influences (school counselor caseload and percentage of time spent on college-readiness counseling). Reference categories: FGCS = non-FGCS; Sex = male; Race/ethnicity = White; STEM GPA = 3.0-4.0; Percentage of time spent on college-readiness counseling $=$ less than $21 \%$.

${ }^{*} p<.05 .{ }^{* *} p<.01 .{ }^{* * *} p<.001$. 
Model 1 was significant, $F(9,189)=12.49, p<.001$. McFadden's R Square was 0.0506, indicating that the model explains $5.06 \%$ of the variance outcomes. This model indicated that SES significantly predicted STEM major attainment and persistence $(\beta=0.22, p<.001)$. In addition, female students were less likely than males to report STEM major attainment and persistence $(\beta=-0.94, p<.001)$. Asian students were significantly more likely than White students to report STEM major attainment and persistence $(\beta=0.91, p<.001)$.

Model 2 was significant, $F(12,185)=19.03, p<0.001$, McFadden's R Square $=0.0966$. STEM GPA significantly predicted STEM major attainment and persistence, with students with GPAs ranging from $0.25-2.75$ being significantly less likely to report STEM attainment and persistence compared to students with GPAs of 3.00-4.00 $(\beta=-0.64, p<.001)$. Both math self-efficacy $(\beta=0.27, p<.001)$ and science self-efficacy $(\beta=0.26, p<.001)$ were significant predictors of STEM major attainment and persistence, with increases in these variables resulting in higher odds of the outcome. Female sex and Asian race identity remained significant, while SES was no longer significant.

Model 3 was significant, $F(14,178)=15.90, p<.001$, McFadden's R Square $=0.1005$. For Model 3 , the Archer-Lemeshow goodness-of-fit test was not significant, and the adjusted Wald test was significant, indicating good model fit. In this model, school counselor percentage of time spent on college-readiness counseling predicted student STEM major attainment and persistence, with $21 \%$ or more time spent on college-readiness counseling being more likely to result in the outcome, compared to $20 \%$ or less time spent on college-readiness counseling $(\beta=.26, p<.05)$. School counselor's caseload was not significant. Female sex, Asian race identity, STEM GPA, math selfefficacy, and science self-efficacy all remained significant predictors in the final model. The model correctly classified $77.34 \%$ of the cases, with higher specificity $(95.94 \%)$ than sensitivity $(19.40 \%)$.

\section{Discussion}

A sequential logistic regression analysis provided the means for exploration of the research question: Do school counselor caseload and percentage of time spent on college-readiness counseling predict STEM major attainment and persistence? Sequential logistic regression allowed for sociocultural context to be considered in the prediction of STEM career-related performance. This is important because the structure of opportunity (e.g., SES, education access, social support), socialization of gender roles, and other societal and family norms influence abilities, self-efficacy, outcome expectations, and goals within SCCT (Lent \& Brown, 1996). The first model included person inputs and background environmental influences (Lent et al., 1994), including FGCS status, race/ethnicity, sex, and SES. Students of Asian race/ ethnicity had higher odds of persisting in a STEM major or attaining a degree, compared to the White student reference group, which echoes previous research (Chen, 2013; Mau, 2016). SES also predicted the outcome, with students of higher SES having higher odds of STEM persistence and attainment, which is aligned with previous research on students' SES status and STEM outcomes (Chen, 2013). Finally, female students had lower odds of persisting in a STEM major or attaining a STEM degree than male students in the model; this gender disparity in STEM academic and career-related outcomes has also been noted in the literature (Mau, 2016).

The second model extended the investigation of predictors of STEM major attainment and persistence to include self-efficacy variables (i.e., math self-efficacy, science self-efficacy) and STEM high school GPA, in addition to still accounting for the person inputs and background environmental influences. Within this second model, Asian-identifying students and female students held the same patterns of significance as in the first model, which was that Asian-identifying students had higher 
odds of attaining or persisting, while female students had lower odds. When accounting for the selfefficacy variables, Hispanic-identifying students then showed significantly higher odds of persisting in a STEM major and attaining a STEM degree. Previous research does not report higher odds of Hispanic student STEM major persistence and attainment (Mau, 2016; NSF, 2021). However, this result in the model suggests that when Hispanic students have equitable math self-efficacy, science self-efficacy, and STEM GPAs, their opportunity for STEM success is increased, which has been reflected in an SCCT academic persistence model with Latinx engineering student participants (Lee et al., 2015). STEM self-efficacy is an important subject for school counselors to address with students (Falco, 2017), given its influential role in STEM outcomes (Mau \& Li, 2018; Shaw \& Barbuti, 2010).

The second model demonstrated that as math self-efficacy and science self-efficacy scores increased, the odds of a student persisting in a STEM major or attaining a STEM degree increased significantly. Further, students with higher STEM GPAs in high school were more likely to persist in STEM majors or attain a STEM degree. This is aligned with SCCT, which suggests previous learning experiences and prior accomplishments have a positive effect on career-related outcomes (Lent \& Brown, 1996). Previous research (Chen, 2013) has also suggested that lack of preparation in advanced STEM courses in high school leads to more STEM major attrition.

The final model included all previous variables and added the two school counseling access variables: school counselor caseload and school counselor percentage of time spent on college-readiness counseling. Variables that remained significant in the model, in the same directionality of odds of the outcome, were: Asian race/ethnicity, Hispanic race/ethnicity, sex, math self-efficacy, science self-efficacy, and high school STEM GPA. The final model showed women were less likely to persist in STEM majors or attain a STEM degree even when accounting for the access to school counseling variables. This gender disparity is unfortunately reflective of the extant literature on STEM outcomes (Chen, 2013). It also perhaps speaks to the barriers school counselors face when working with historically underrepresented students surrounding STEM (Cabell et al., 2021), such as a lack of encouragement from educators for girls to pursue STEM endeavors (Grossman \& Porche, 2014).

In the current study, school counselor caseload was not significant in the model. This finding is not aligned with previous research that found the addition of each school counselor to a school's staff was associated with a 10\% increase in 4-year college-going rates (Hurwitz \& Howell, 2014), which suggests the influence of caseload on student postsecondary outcomes, as typically more school counselors on staff results in lower caseloads. However, it is important to note that school counselor caseload did have a significant relationship with the percentage of time spent on college-readiness counseling in the current study, with more students on a caseload resulting in less time spent on college-readiness counseling, according to the bivariate correlation analysis.

School counselor percentage of time spent on college-readiness counseling was significant in the final model, and the results indicated that students who have a school counselor who spends at least the national average of time on college-readiness counseling (i.e., 21\%) have higher odds of persisting in STEM majors or attaining a STEM degree. Students who have a school counselor who spends $21 \%$ or more of their time on college-readiness counseling have $29 \%$ higher odds of STEM major persistence and attainment 3 years post-high school graduation. This finding is novel in the literature. School counseling and STEM counseling is a relatively new area of research in the school counseling literature (Falco, 2017; Schmidt et al., 2012). The current study's finding on the impact of school counselors' college-readiness counseling on STEM outcomes extends existing research that has noted the importance of school counselors' role in STEM counseling (Falco, 2017; Falco \& Summers, 2019; Shillingford et al., 2017). 


\section{Implications}

School counselors can use the results of this study to inform their STEM education-focused collegereadiness counseling work. A promising result of the study was that school counselors' percentage of time spent on college-readiness counseling was predictive of STEM major attainment and persistence. Although there were still inequities in which students were achieving this outcome, including female students. This is helpful information to lead school counselors to target intervention efforts with girls. For instance, girls may benefit from more STEM-focused occupational information and verbal persuasion (i.e., encouragement) from school counselors. These results indicate that school counselors should increase their knowledge and awareness of the barriers their female students are facing related to STEM and seek to correct those barriers. Barriers can include school climate, which school counselors can address through both the messages they themselves and all school staff are sending to their female students about STEM. In terms of consultation, it has been suggested school counselors should play an important role in working with STEM teachers to develop curricula that are unbiased and culturally sensitive to the needs of female and minority students, and the results of the study show the long-lasting effects of how a ninth-grade student perceives their self-efficacy in math and science, supporting this suggestion (Mau, 2016).

Additionally, high school STEM GPA was predictive of persisting and attaining a STEM degree. School counselors encourage high achievement from all students, and this result does not suggest that school counselors should focus their STEM career exploration on just those students who have higher STEM GPAs, assuming those with lower STEM GPAs will not want to enroll as STEM majors in college or cannot be successful once there. All students, regardless of STEM GPA, should receive STEM counseling opportunities. School counselors should also strive to create an environment that is inclusive for all students to be successful in STEM. Further, school counselors can connect their students to the resources to support their success in STEM coursework.

Math and science self-efficacy were important predictive factors of persistence and attainment in a STEM degree, and these areas of self-efficacy can be targeted through interventions with students; previous literature has provided suggestions on how school counselors can do so (Falco, 2017; Schmidt et al., 2012; Shillingford et al., 2017). Developing STEM self-efficacy is important, because when this was held constant, there were no students of different races/ethnicities who were at lower odds of persisting and attaining a STEM degree, nor did SES have an influence on outcomes. School counselors must remain vigilant of the structural inequalities underrepresented students face and remove these barriers (Wolniak et al., 2016).

The results of this study also emphasize the importance of counselor educators intentionally discussing STEM career development in the career counseling and other school counseling curriculum. Research has shown school counselors do not feel knowledgeable about careers in the STEM fields and desire more STEM content information to inform their work (Cabell et al., 2021; Hall et al., 2011). STEM counseling within the school counselor repertoire is a relatively new topic (Schmidt et al., 2012), and counselor educators must be aware of this counseling area and incorporate it into their curriculum.

Additionally, the results of this study support the need for collaborations between university counseling programs and neighboring school districts to increase counseling access and improve underrepresented students' STEM outcomes. Finally, both counselor educators and school counselors can use the results of this study, and the many others that have proven the effectiveness of school counseling, to advocate for lower counselor-to-student ratios and more funding for school counselors. 


\section{Limitations and Future Research}

There are limitations to utilizing secondary analysis of existing data. Specifically, researchers are not privy to selection of the variables and the researchers' bias can influence which variables are selected to study an outcome; there are many more variables in this dataset which could be included for an exploration of the research question (Cheng \& Phillips, 2014). However, the use of the NCES-led HSLS:09 dataset allowed for an extensive number of variables for a massive longitudinal study (NCES, 2020a). A potential area for future exploration in this model could also be school counselors' self-efficacy in college counseling and STEM counseling and how that impacts students' outcomes. Further, causal inferences should not be assumed in logistic regression models; probability in correctly predicting an outcome does not mean that these variables cause the outcomes (Tabachnick \& Fidell, 2013).

Future research studies could utilize multilevel modelling methods to account for school-level variables, such as staff-to-student ratio, percentage of students on free-and-reduced lunch, and geographic area. This would further investigate systemic influences on access to school counseling and student outcomes and could have the potential to increase the percentage of variance accounted for by the models. Additionally, there has recently been follow-up data added to the HSLS:09 dataset, which includes postsecondary transcripts; this study could be replicated with this data.

Research on school counselors and STEM is growing and should be continued. For instance, researchers have explored school counselors' experiences regarding STEM and STEM counseling (Cabell et al., 2021; Shillingford et al., 2017). Quantitative research surrounding this topic is needed as well to measure differences in STEM counseling allocation and student STEM outcomes as a result of school counselors' preparation and efficacy in this area. Finally, an understanding of how counselor education programs are and are not preparing their students to engage in college-readiness counseling and STEM counseling is warranted.

\section{Conclusion}

This study provides encouraging results regarding the impact of school counselors' college-readiness counseling on students' STEM major attainment and persistence. Results detailed how science and math self-efficacy had strong predictive power on STEM outcomes, which informs school counseling practice. Through increased training in college-readiness counseling and STEM counseling in school counseling training programs, and continued attention to a holistic model of college readiness, school counselors can continue to play an integral role in all students' college and STEM readiness through providing college-readiness counseling (Gilfillan, 2017; Schmidt et al., 2012).

\section{Conflict of Interest and Funding Disclosure}

Data collected and content shared in this article were part of a dissertation study, which was awarded the 2021 Dissertation Excellence Award by the National Board for Certified Counselors. 
The Professional Counselor I Volume 11, Issue 4

\section{References}

American School Counselor Association. (2019). The ASCA national model: A framework for school counseling programs (4th ed.).

Bandura, A. (1986). Social foundations of thought and action: A social cognitive theory. Prentice-Hall.

Bandura, A. (1994). Self-efficacy. In V. S. Ramachaudran (Ed.), Encyclopedia of human behavior (Vol. 4, pp. 71-81). Academic Press.

Belser, C. T., Shillingford, M. A., Daire, A. P., Prescod, D. J., \& Dagley, M. A. (2018). Factors influencing undergraduate student retention in STEM majors: Career development, math ability, and demographics. The Professional Counselor, 8(3), 262-276. https://doi.org/10.15241/ctb.8.3.262

Brown, S. D., \& Lent, R. W. (1996). A social cognitive framework for career choice counseling. The Career Development Quarterly, 44(4), 354-366. https://doi.org/10.1002/j.2161-0045.1996.tb00451.x

Cabell, A. L., Brookover, D., Livingston, A., \& Cartwright, I. (2021). "It's never too late": High school counselors' support of underrepresented students' interest in STEM. The Professional Counselor, 11(2), 143-160. https://doi.org/10.15241/alc.11.2.143

Cataldi, E. F., Siegel, P., Shepherd, B., \& Cooney, J. (2014). Baccalaureate and beyond: A first look at the employment experiences and lives of college graduates, 4 Years On (BEB:08/12) (NCES 2014-141). National Center for Education Statistics, Institute of Education Sciences, U.S. Department of Education. https://nces.ed.gov/ pubs2014/2014141.pdf

Chen, X. (2013). STEM attrition: College students' paths into and out of STEM fields (NCES 2014-001). National Center for Education Statistics, Institute of Education Sciences, U.S. Department of Education. https://nces.ed.gov/pubs2014/2014001rev.pdf

Cheng, H. G., \& Phillips, M. R. (2014). Secondary analysis of existing data: Opportunities and implementation. Shanghai Archives of Psychiatry, 26(6), 371-375. https://doi.org/10.11919/j.issn.1002-0829.214171

Clinedinst, M., \& Koranteng, A.-M. (2017). 2017 state of college admission. National Association for College Admission Counseling. https://bit.ly/3BNizx8

Duprey, M. A., Pratt, D. J., Jewell, D. M., Cominole, M. B., Fritch, L. B., Ritchie, E. A., Rogers, J. E., Wescott, J. D., \& Wilson, D. H. (2018). High School Longitudinal Study of 2009 (HSLS:09) base-year to second follow-up data file documentation (NCES 2018-140). National Center for Education Statistics, Institute of Education Sciences, U.S. Department of Education. https://nces.ed.gov/pubs2018/2018140.pdf

Engberg, M. E., \& Gilbert, A. J. (2014). The counseling opportunity structure: Examining correlates of four-year college-going rates. Research in Higher Education, 55(3), 219-244.

Falco, L. D. (2017). The school counselor and STEM career development. Journal of Career Development, 44(4), 359-374. https://doi.org/10.1177/0894845316656445

Falco, L. D., \& Summers, J. J. (2019). Improving career decision self-efficacy and STEM self-efficacy in high school girls: Evaluation of an intervention. Journal of Career Development, 46(1), 62-76. https://doi.org/10.1177/0894845317721651

Gilfillan, B. H. (2017). School counselors and college readiness counseling. Professional School Counseling, 21(1). https://doi.org/10.1177/2156759X18784297

Grossman, J. M., \& Porche, M. V. (2014). Perceived gender and racial/ethnic barriers to STEM success. Urban Education, 49(6), 698-727. https://doi.org/10.1177/0042085913481364

Hall, C., Dickerson, J., Batts, D., Kauffmann, P., \& Bosse, M. (2011). Are we missing opportunities to encourage interest in STEM fields? Journal of Technology Education, 23(1), 32-46. https://files.eric.ed.gov/fulltext/EJ96 5337.pdf

Hurwitz, M., \& Howell, J. (2014). Estimating causal impacts of school counselors with regression discontinuity designs. Journal of Counseling \& Development, 92(3), 316-327. https://doi.org/10.1002/j.1556-6676.2014.00159.x

Ingels, S. J., \& Dalton, B. (2013). High School Longitudinal Study of 2009 (HSLS:09) first follow-up: A first look at fall 2009 ninth graders in 2012 (NCES 2014-360). National Center for Education Statistics, Institute of Education Sciences, U.S. Department of Education. https://nces.ed.gov/pubs2014/2014360.pdf

Lavrakas, P. J. (Ed.). (2008). Encyclopedia of survey research methods (Vols. I-II). SAGE. 
Lee, H.-S., Flores, L. Y., Navarro, R. L., \& Kanagui-Muñoz, M. (2015). A longitudinal test of social cognitive career theory's academic persistence model among Latino/a and White men and women engineering students. Journal of Vocational Behavior, 88, 95-103. https://doi.org/10.1016/j.jvb.2015.02.003

Lent, R. W. (2005). A social cognitive view of career development and counseling. In S. D. Brown \& R. W. Lent (Eds.), Career development and counseling: Putting theory and research to work (pp. 101-127). Wiley.

Lent, R. W., \& Brown, S. D. (1996). Social cognitive approach to career development: An overview. The Career Development Quarterly, 44(4), 310-321. https://doi.org/10.1002/j.2161-0045.1996.tb00448.x

Lent, R. W., Brown, S. D., \& Hackett, G. (1994). Toward a unifying social cognitive theory of career and academic interest, choice, and performance. Journal of Vocational Behavior, 45(1), 79-122. https://doi.org/10.1006/jvbe.1994.1027

Lent, R. W., Brown, S. D., \& Hackett, G. (2000). Contextual supports and barriers to career choice: A social cognitive analysis. Journal of Counseling Psychology, 47(1), 36-49. https://doi.org/10.1037/0022-0167.47.1.36

Lent, R. W., Miller, M. J., Smith, P. E., Watford, B. A., Lim, R. H., \& Hui, K. (2016). Social cognitive predictors of academic persistence and performance in engineering: Applicability across gender and race/ethnicity. Journal of Vocational Behavior, 94, 79-88. https://doi.org/10.1016/j.jvb.2016.02.012

Lips, H. M. (2020). Sex and gender: An introduction (7th ed.). Waveland Press.

Malin, J. R., Bragg, D. D., \& Hackmann, D. G. (2017). College and career readiness and the Every Student Succeeds Act. Educational Administration Quarterly, 53(5), 809-838. https://doi.org/10.1177/0013161X17714845

Mau, W.-C. J. (2016). Characteristics of US students that pursued a STEM major and factors that predicted their persistence in degree completion. Universal Journal of Educational Research, 4(6), 1495-1500. https://doi.org/10.13189/ujer.2016.040630 https://files.eric.ed.gov/fulltext/EJ1103170.pdf

Mau, W.-C. J., \& Li, J. (2018). Factors influencing STEM career aspirations of underrepresented high school students. The Career Development Quarterly, 66(3), 246-258. https://doi.org/10.1002/cdq.12146

Meyers, L. S., Gamst, G., \& Guarino, A. J. (2017). Applied multivariate research: Design and implementation (3rd ed.). SAGE.

Mohr-Schroeder, M. J., Cavalcanti, M., \& Blyman, K. (2015). STEM education: Understanding the changing landscape. In A. Sahin (Ed.), A practice-based model of STEM teaching: STEM Students on the Stage (SOS) (pp. 3-14). Sense. https://doi.org/10.1007/978-94-6300-019-2

National Center for Education Statistics. (2020a). High School Longitudinal Study of 2009 (HSLS:09) [Data set]. Institute of Education Sciences. https://nces.ed.gov/surveys/hsls09/hsls09 data.asp

National Center for Education Statistics. (2020b). High School Longitudinal Study of 2009 (HSLS:09). https://nce s.ed.gov/surveys/hsls09/index.asp

National Center for Education Statistics. (2020c). College enrollment rates. Institute of Education Sciences. https://nces.ed.gov/programs/coe/indicator cpb.asp

National Science Foundation. (2021). Women, minorities, and persons with disabilities in science and engineering: 2021. National Center for Science and Engineering Statistics Special Report NSF 19-304. https://www.ns f.gov/statistics/wmpd

Rittmayer, A. D., \& Beier, M. E. (2009). Self-efficacy in STEM. In B. Bogue \& E. Cady (Eds.), Applying research to practice (ARP) Resources. http://aweonline.org/selfefficacy 002.html

Savitz-Romer, M. (2012). The gap between influence and efficacy: College readiness training, urban school counselors, and the promotion of equity. Counselor Education and Supervision, 51(2), 98-111, 158. https://doi.org/10.1002/j.1556-6978.2012.00007.x

Schmidt, C. D., Hardinge, G. B., \& Rokutani, L. J. (2012). Expanding the school counselor repertoire through STEM-focused career development. The Career Development Quarterly, 60(1), 25-35. https://doi.org/10.1002/j.2161-0045.2012.00003.x

Shaw, E. J., \& Barbuti, S. (2010). Patterns of persistence in intended college major with a focus on STEM majors. NACADA Journal, 30(2), 19-34. https://doi.org/10.12930/0271-9517-30.2.19

Shillingford, M. A., Oh, S., \& Finnell, L. R. (2017). Promoting STEM career development among students and parents of color: Are school counselors leading the charge? Professional School Counseling, 21(1b), 1-11. https://doi.org/10.1177/2156759X18773599

Sperandei, S. (2014). Understanding logistic regression analysis. Biochemia Medica, 24(1), 12-18. https://doi.org/10.11613/BM.2014.003 
Tabachnick, B. G., \& Fidell, L. S. (2013). Using multivariate statistics (6th ed.). Pearson.

Tsupros, N., Kohler, R., \& Hallinen, J. (2009). STEM education: A project to identify the missing components [Summary report]. Intermediate Unit 1: Center for STEM Education and Leonard Gelfand Center for Service Learning and Outreach, Carnegie Mellon University, Pennsylvania.

U.S. Department of Education. (2010). A blueprint for reform: The reauthorization of the Elementary and Secondary Education Act. Office of Planning, Evaluation and Policy Development. https://www.ets.org/s/education topics/ESEA Blueprint.pdf

Vilorio, D. (2014). STEM 101: Intro to tomorrow's jobs. Occupational Outlook Quarterly, Spring, 58, 3-12. https://www.bls.gov/careeroutlook/2014/spring/art01.pdf

The White House, Office of Science and Technology Policy, National Science and Technology Council. (2018). Charting a course for success: America's strategy for STEM education. Office of Science and Technology Policy. https://www.energy.gov/sites/default/files/2019/05/f62/STEM-Education-Strategic-Plan-2018.pdf

Wolniak, G. C., Wells, R. S., Engberg, M. E., \& Manly, C. A. (2016). College enhancement strategies and socioeconomic inequality. Research in Higher Education, 57(3), 310-334. https://doi.org/10.1007/s11162-015-9389-4

Xue, Y., \& Larson, R. C. (2015). STEM crisis or STEM surplus? Yes and yes. Monthly Labor Review. U.S. Bureau of Labor Statistics. https://doi.org/10.21916/mlr.2015.14 